\title{
HAEMODYNAMIC EFFECTS OF SQUATTING DURING REPOSE*
}

\author{
BY \\ LEON BROTMACHER \\ From the Cardiac Department, Guy's Hospital \\ Received May 30, 1957
}

The tendency of children with cyanotic congenital heart disease to squat when tired or breathless was described by Taussig in 1947, but the reasons for the adoption of this striking posture have been surprisingly little studied. Lurie (1953) found that inflating cuffs on the thighs obviates the need to squat and suggested that venous reservoirs in the legs are compressed and brought nearer to heart level by squatting: the effects of gravity, which causes pooling of blood in the legs and a fall in cardiac output with standing, are thereby countered. Callebaut et al. (1949), on the basis of oximetric studies, suggested that squatting increases systemic resistance and reduces the venoarterial shunt. With these exceptions, virtually no investigations into the hæmodynamic effect of squatting have been made in cyanotic patients.

The present investigation was made to try to explain the tendency of severely incapacitated patients with cyanotic congenital heart disease to lie continuously in a squatting position, even when they have not been exercising. The effects of squatting in an upright position during recovery from exercise are considered in a separate communication (Brotmacher, 1957b). Patients with acyanotic congenital heart disease and subjects with normal hearts have also been studied in an attempt to determine whether the changes observed are peculiar to squatters or are general ones that benefit patients with a veno-arterial shunt as a result of their cardiac abnormality.

\section{Material AND Methods}

Measurements of the effect of squatting on systemic and pulmonary blood flow were made on 13 squatters and 17 control subjects. $\dagger$

In order to obtain the maximum possible co-operation from patients who were not being anæsthetized, they were shown the room in which the procedure was to be carried out, and this was explained in an appropriate manner. Sodium amytal was given an hour before starting. All examinations were performed in the morning, the patients having fasted since the previous evening, apart from a cup of tea at least two hours before. Anæsthesia, when used, was induced by thiopentone sodium given intravenously or injected down the catheter. The patients had invariably been in position for at least half an hour before the control observations were made. The position usually adopted by the squatters when recumbent was then reproduced as far as possible. The legs were passively flexed, slightly abducted and laterally rotated at the hips, and flexed at the knees, the thighs being brought as near as possible to the flanks. The legs were supported in this position so that no exertion was required of the patients.

Blood samples were obtained after the patient had been in position about one minute, and at least five minutes were allowed to elapse between lowering the legs and obtaining control blood samples at other sites. The oxygen consumption was measured over periods of two to four minutes with the patient breathing air, a modification of the Benedict spirometer (Christie and Donald, 1949) being used. The blood oxygen content was measured by the Haldane method (Douglas and Priestley, 1948) and oxygen capacity calculated from the hæmoglobin percentage, which was determined by photo-electric colorimetry.

* Work forming part of a thesis accepted for the degree of Ph.D. by the University of London. $\dagger$ Further particulars relating to these patients are contained in an appendix that is available on request. $2 \mathbf{P}$ 559 
The values obtained were used to calculate the blood flows by application of the Fick principle. The criteria for recognition of an arterio-venous shunt were those described by Holling and Zak (1950), and an arterial oxygen of less than 94 per cent was regarded as indicative of a veno-arterial shunt. When necessary, pulmonary venous blood was assumed to have an oxygen saturation of 96 per cent.

A number of observations were made in patients being anæsthetized for angiocardiography. Rectal thiopentone sodium was used for premedication and anæsthesia maintained with cyclopropane, the depth required being somewhat greater than that needed for cardiac catheterization: Observations were made with the patient breathing pure oxygen, and full saturation of pulmonary venous blood assumed. Oxygen consumption was measured with a Benedict spirometer, using oxygen, and a sample of mixed venous blood obtained at the same time, a cardiac catheter having previously been advanced as far as the right atrium. The catheter was then withdrawn and the investigation continued in the usual way. As an inhalation anæsthetic was employed, the Haldane method of blood gas analysis could not be used. The oxygen contents and capacities were therefore estimated with the Beckman spectrophotometer.

Pressures were measured with Southern Instruments capacitance electromanometers connected to a Brush oscillograph. In all but one patient, in whom the aorta was intubated through a persistent ductus arteriosus, systemic pressures were recorded in the brachial artery, which was punctured with a 21-gauge needle connected to the electromanometer by plastic tubing of $2 \mathrm{~mm}$. internal bore. All pressures were measured from midway between the sternal angle and the tip of the fourth thoracic spinous process.

In the absence of a veno-arterial shunt, the arterial oxygen content remains remarkably constant. Observations in four control subjects (Table I) showed that it was not altered appreciably by squatting, and in the

TABLE I

EfFect of SQuatting on Arterial Oxygen

A. Samples obtained during cardiac catheterization

\begin{tabular}{|c|c|c|c|c|c|c|c|}
\hline \multirow{2}{*}{ Case No. } & \multicolumn{3}{|c|}{ Arterial $\mathrm{O}_{2}$ content $(\mathrm{ml} . / 100 \mathrm{ml})}$. & \multirow{2}{*}{ Case No. } & \multicolumn{3}{|c|}{$\begin{array}{c}\text { Arterial } \mathrm{O}_{2} \text { content }(\mathrm{ml} . / 100 \mathrm{ml} .) \\
\text { Squatters }\end{array}$} \\
\hline & Supine & Squatting & Difference & & Supine & Squatting & Difference \\
\hline $\begin{array}{r}10 \\
12 \\
, 31 \\
32\end{array}$ & $\begin{array}{l}14 \cdot 0 \\
15 \cdot 7 \\
17 \cdot 5 \\
19 \cdot 3\end{array}$ & $\begin{array}{l}13.9 \\
15 \cdot 5 \\
17.4 \\
19 \cdot 2\end{array}$ & $\begin{array}{l}-0.1 \\
-0.2 \\
-0.1 \\
-0.1\end{array}$ & $\begin{array}{l}21 \\
22 \\
23 \\
24 \\
33\end{array}$ & $\begin{array}{l}24.6 \\
23.6 \\
15.3 \\
16 \cdot 3 \\
27.8\end{array}$ & $\begin{array}{l}24.3 \\
23.5 \\
15.4 \\
16.8 \\
28.0\end{array}$ & $\begin{array}{r}-0.3 \\
-0.1 \\
+0.1 \\
+0.5 \\
+0.2\end{array}$ \\
\hline
\end{tabular}

B. Oximetric observations on squatters

\begin{tabular}{c|c|c|c}
\hline & \multicolumn{3}{|c|}{ Percentage saturation of arterial blood } \\
\cline { 2 - 4 } Case No. & Supine & Squatting & Supine \\
\hline 22 & 89 & 88 & 89 \\
23 & 95 & 95 & 95 \\
27 & 87 & 87 & 87 \\
34 & 97 & 97 & 97 \\
35 & 94 & 92 & 94 \\
\hline
\end{tabular}

remaining acyanotic patients it was assumed to be the same when squatting as when supine. This assumption was also made in four squatters: it has been shown by volumetric analysis and by ear oximetry (Table I) that squatting does not alter the oxygen saturation of these patients appreciably. In four subjects an arterial sample was not obtained. There was no history of cyanosis and no hæmodynamic basis for a veno-arterial shunt; their systemic and pulmonary flows were calculated on an assumed 96 per cent saturation of pulmonary venous and systemic arterial blood. In one patient with, inter alia, an atrial septal defect, no inferior vena caval sample was obtained while squatting. The superior vena caval oxygen content remained unchanged and that of pulmonary arterial and right atrial blood changed by only 0.1 and $0.2 \mathrm{ml} . / 100 \mathrm{ml}$. respectively. Flows when squatting were calculated on a presumed absence of alteration in the saturation of mixed venous blood.

\section{RESULTS}

Fourteen observations of the effect of squatting on systemic blood flow were made in control subjects (Table II). In all but two the flow was higher when squatting than when supine. There 
was no change in systemic blood flow in one of the exceptions and a two per cent fall in the second, who was thought to have primary pulmonary hypertension and gave a history of syncopal attacks on exertion and may well have had a fixed cardiac output. The mean increase for the entire group was 42 per cent and the maximum 108 per cent.

There was a tendency for the arterio-venous oxygen difference to lessen (Table II), but the changes were small in extent and not consistent. The mean decrease was less than $0.4 \mathrm{ml} . / 100 \mathrm{ml}$. The increase in systemic blood flow was associated for the most part with a rise in oxygen consumption, which was observed in all but two subjects (Table II). The changes in these two para-

TABLE II

Effect of Squatting on Oxygen Consumption, Arterio-venous Difference and Systemic Blood Flow. CONTROL SUBJECTS

\begin{tabular}{|c|c|c|c|c|c|c|}
\hline \multirow{2}{*}{ Case No. } & \multicolumn{2}{|c|}{$\begin{array}{l}\text { Oxygen consumption } \\
(\mathrm{ml} . / \mathrm{min} .)\end{array}$} & \multicolumn{2}{|c|}{$\begin{array}{c}a-v \text { difference } \\
(\mathrm{ml} . / 100 \mathrm{ml} .)\end{array}$} & \multicolumn{2}{|c|}{$\begin{array}{l}\text { Systemic flow } \\
\text { (1./min.) }\end{array}$} \\
\hline & Supine & Squatting & Supine & Squatting & Supine & Squatting \\
\hline $\begin{array}{r}1 \\
2 \\
3 \\
4 \\
5 \\
6 \\
7 \\
8 \\
9 \\
10 \\
11 \\
12 \\
13 \\
14 \\
15\end{array}$ & $\begin{array}{l}192 \\
213 \\
158 \\
208 \\
129 \\
134 \\
166 \\
214 \\
141 \\
115 \\
247 \\
145 \\
207 \\
145 \\
104\end{array}$ & $\begin{array}{l}176 \\
231 \\
160 \\
237 \\
149 \\
162 \\
199 \\
251 \\
196 \\
225 \\
263 \\
193 \\
244 \\
145 \\
125\end{array}$ & $\begin{array}{l}6 \cdot 0 \\
6.0 \\
7 \cdot 4 \\
3 \cdot 3 \\
1.5 \\
5 \cdot 1 \\
5 \cdot 5 \\
4 \cdot 5 \\
3 \cdot 2 \\
4 \cdot 3 \\
2 \cdot 7 \\
4 \cdot 3 \\
4 \cdot 2 \\
4 \cdot 9\end{array}$ & $\begin{array}{l}4.5 \\
4.7 \\
7.0 \\
3.6 \\
0.9 \\
4.3 \\
4.1 \\
4.7 \\
3.0 \\
4.7 \\
1.9 \\
4.2 \\
4.2 \\
5.2\end{array}$ & $\begin{array}{l}3.2 \\
3.5 \\
2.8 \\
3.9 \\
8.9 \\
3.2 \\
3.9 \\
3.1 \\
3 \cdot 6 \\
5 \cdot 7 \\
5.4 \\
4.8 \\
3.5 \\
2 \cdot 1\end{array}$ & $\begin{array}{r}3.9 \\
4.9 \\
3.0 \\
4.2 \\
18.0 \\
6.3 \\
6.1 \\
4.1 \\
7.5 \\
5.6 \\
10.2 \\
5.8 \\
3.5 \\
2.4\end{array}$ \\
\hline
\end{tabular}

meters do not bear a very close relationship, but the subjects who had a large increase of systemic flow had also a large increase of oxygen consumption. There was no relationship between the initial levels of the oxygen consumption and the arterio-venous oxygen difference on the one hand, and the changes produced by squatting on the other.

Eight observations on the effect of squatting on systemic blood flow were made in squatters (Table III). In all but one, the flow increased. The mean percentage increase for the whole group was 24 and the maximum 100. The changes in the arterio-venous oxygen difference were small and inconstant in this group as in the controls (Table II), the mean change being only $0 \cdot 2 \mathrm{ml} . / 100 \mathrm{ml}$.

TABLE III

Effect of Squatting on Oxygen Consumption, Arterio-venous Difference and Blood Flow. Squatters

\begin{tabular}{|c|c|c|c|c|c|c|c|c|}
\hline \multirow{2}{*}{$\begin{array}{l}\text { Case } \\
\text { No. }\end{array}$} & \multicolumn{2}{|c|}{$\begin{array}{l}\text { Oxygen consumption } \\
\text { (ml./min.) }\end{array}$} & \multicolumn{2}{|c|}{$\begin{array}{l}a-v \text { difference } \\
(\mathrm{ml} . / 100 \mathrm{ml} .)\end{array}$} & \multicolumn{2}{|c|}{$\begin{array}{l}\text { Systemic flow } \\
\text { (1./min.) }\end{array}$} & \multicolumn{2}{|c|}{$\begin{array}{c}\text { Effective pulmonary flow } \\
\text { (1./min) }\end{array}$} \\
\hline & Supine & Squatting & Supine & Squatting & Supine & Squatting & Supine & Squatting \\
\hline $\begin{array}{l}18 \\
19 \\
20 \\
21 \\
22 \\
23 \\
24 \\
25 \\
26 \\
27\end{array}$ & $\begin{array}{r}164 \\
186 \\
325 \\
162 \\
230 \\
140 \\
227 \\
98 \\
190 \\
231\end{array}$ & $\begin{array}{l}172 \\
238 \\
410 \\
318 \\
203 \\
195 \\
249 \\
124 \\
176 \\
209\end{array}$ & $\begin{array}{l}4 \cdot 1 \\
3 \cdot 5 \\
4 \cdot 2 \\
4 \cdot 5 \\
4 \cdot 0 \\
4.9 \\
8 \cdot 0 \\
3 \cdot 3 \\
=\end{array}$ & $\begin{array}{l}3.5 \\
3.9 \\
5.2 \\
4.4 \\
4.9 \\
5.3 \\
7.6 \\
3.3 \\
=\end{array}$ & $\begin{array}{l}4.0 \\
5.3 \\
7.7 \\
3.6 \\
5.8 \\
2.9 \\
2.8 \\
3.0 \\
=\end{array}$ & $\begin{array}{l}4.9 \\
6.1 \\
7.9 \\
7.2 \\
4.2 \\
3.7 \\
3.3 \\
3.8 \\
=\end{array}$ & $\begin{array}{l}2 \cdot 0 \\
5 \cdot 5 \\
6 \cdot 8 \\
2 \cdot 7 \\
2 \cdot 3 \\
2 \cdot 9 \\
2 \cdot 3 \\
2 \cdot 4 \\
2 \cdot 6 \\
7.2\end{array}$ & $\begin{array}{l}2.2 \\
6.2 \\
7.0 \\
5.1 \\
1.8 \\
3.7 \\
2.8 \\
3.0 \\
2.8 \\
4.9\end{array}$ \\
\hline
\end{tabular}

The major alterations in systemic flow were associated with oxygen consumption changes (Table III). Again, there was no relationship between the initial levels of the arterio-venous oxygen difference on the one hand, and the changes occurring with squatting on the other; nor were the changes in the one related to the changes in the other. 
The changes in oxygen consumption of the squatters and the control subjects were selected for comparison, as the most data were available for this parameter, and no assumptions had to be made in its measurement. There was a mean increase of 21 per cent in the squatters and 20 per cent in the controls. The difference between these means is obviously not significant (P>0.9).

The effective pulmonary blood flow was increased in eight out of ten squatters (Table III). In the two control subjects with veno-arterial shunts the effective pulmonary flows increased from 2.4 to 4.0 and from 3.0 to $4.21 . / \mathrm{min}$. respectively. In the patients with no veno-arterial shunts, the effective pulmonary flow was, of course, identical with the systemic, the changes in which have already been discussed.

In the seven control subjects and the six squatters in whom there was also an arterio-venous shunt, the changes in the total pulmonary blood flow and in the arterio-venous shunt were variable and inconstant, although frequently considerable in extent. In the control subject in whom it was present at rest, the veno-arterial shunt became larger with squatting. There was an increase in the veno-arterial shunt of $1.21 . / \mathrm{min}$. in the squatter who doubled his systemic flow, a decrease of 1.1 1./min. in the patient whose systemic flow decreased, increases of less than $1.01 . / \mathrm{min}$. in two further patients, and no change in the remainder.

The effect of squatting on effective pulmonary blood flow was measured in three squatters and two control subjects who had been anæsthetized for angiocardiography. It increased in one squatter, but was reduced in all the others, the mean decrease in the five patients being 9 per cent (Table IV).

TABLE IV

Effect of Squatting on Cardiac Dynamics. Subjects Investigated when Anasthetized for AngioCARDIOGRAPHY

\begin{tabular}{|c|c|c|c|c|}
\hline Case No. & Position & $\mathrm{O}_{2}$ consumption ( $\left.\mathrm{ml} . / \mathrm{min}.\right)$ & $\mathrm{O}_{2}$ content of R.A. blood ( $\left.\mathrm{ml} . / 100 \mathrm{ml}.\right)$ & Effective pulmonary flow (1./min.) \\
\hline 16 & $\begin{array}{l}\text { Supine } \\
\text { Squatting }\end{array}$ & $\begin{array}{l}171 \\
207\end{array}$ & $\begin{array}{l}21 \cdot 1 \\
19 \cdot 1\end{array}$ & $\begin{array}{l}2 \cdot 2 \\
2 \cdot 1\end{array}$ \\
\hline 17 & $\begin{array}{l}\text { Supine } \\
\text { Squatting }\end{array}$ & $\begin{array}{r}88 \\
108\end{array}$ & $\begin{array}{l}22 \cdot 8 \\
19 \cdot 8\end{array}$ & $\begin{array}{l}1.6 \\
1.4\end{array}$ \\
\hline $28 *$ & $\begin{array}{l}\text { Supine } \\
\text { Squatting }\end{array}$ & $\begin{array}{l}156 \\
116\end{array}$ & $\begin{array}{l}18 \cdot 0 \\
17 \cdot 6\end{array}$ & $\begin{array}{l}2 \cdot 1 \\
1 \cdot 5\end{array}$ \\
\hline $29 *$ & $\begin{array}{l}\text { Supine } \\
\text { Squatting }\end{array}$ & $\begin{array}{l}169 \\
204\end{array}$ & $\begin{array}{l}24 \cdot 6 \\
24 \cdot 6\end{array}$ & $\begin{array}{l}4 \cdot 3 \\
6 \cdot 0\end{array}$ \\
\hline $30 *$ & $\begin{array}{l}\text { Supine } \\
\text { Squatting }\end{array}$ & $\begin{array}{l}144 \\
150\end{array}$ & $\begin{array}{l}17 \cdot 4 \\
14 \cdot 3\end{array}$ & $\begin{array}{l}4 \cdot 4 \\
2 \cdot 3\end{array}$ \\
\hline
\end{tabular}

* Squatters

The pulse rate increased by a mean of 2 beats a minute in the control subjects (S.D. of change $= \pm 7$ beats $/ \mathrm{min}$.) and by 3 beats a minute in the squatters (S.D. of change $= \pm 4$ beats $/ \mathrm{min}$.). The alterations in systemic and pulmonary blood flows resulted almost entirely, therefore, from changes in stroke volume.

The effect of squatting on the oxygen saturation of blood from the upper and lower parts of the body was estimated by comparing the oxygen content of superior and inferior vena caval blood in the supine and squatting positions. The effect on inferior vena caval blood was variable, the mean change being only $-0.04 \mathrm{ml} / 100 \mathrm{ml}$. In the control subjects the oxygen content of superior vena caval blood was reduced by a mean of $0 \cdot 1 \mathrm{ml} / 100 \mathrm{ml}$. The changes were not consistent; there was an increase in four subjects and a decrease in four others. In contrast, increases of 0.3 to $1.8 \mathrm{ml} . / 100 \mathrm{ml}$. were observed in six out of seven squatters, the superior vena caval oxygen content remaining unchanged in the one exception: these changes were highly significant (mean increase $=1.0 \mathrm{ml} . / 100 \mathrm{ml} ., n=7, t=3 \cdot 84,0.01>P>0.001)$.

The effect of squatting on right atrial pressure was measured in 14 patients and the effect on pulmonary capillary venous pressure in 9 . Five of these were squatters. The right atrial pressure 
showed a sharp initial rise of from 2 to $8 \mathrm{~mm}$. Hg with squatting, the change taking place simultaneously with raising of the legs. It was followed by a fall to 1 to $2 \mathrm{~mm}$. $\mathrm{Hg}$ above the control level, and this slight elevation persisted as long as the squatting posture was maintained. When the legs were lowered, the right atrial pressure fell, either to the control level, or very near to it. The changes in pulmonary capillary venous pressure were similar in extent and in timing. In either case there was no obvious difference between the response of the squatters and the control subjects.

In twelve subjects, two of whom were squatters, a total of 21 recordings of the effect of squatting on arterial blood pressure were made. The changes observed are illustrated in Fig. 1. There was

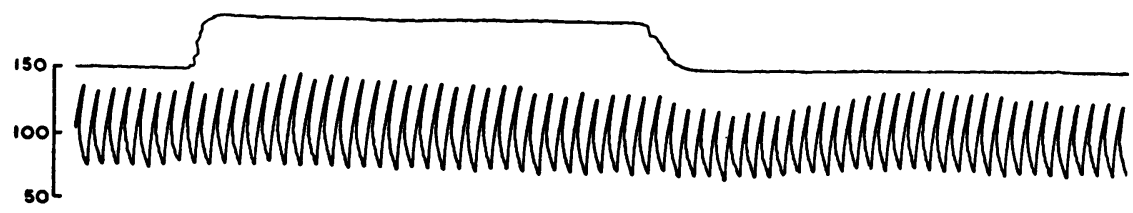

FIG. 1.-Effect of squatting on brachial artery pressure. The upward deflection of the indicator line denotes the onset of squatting: the downward deflection indicates resumption of the supine position.

an immediate increase in systolic and diastolic pressures on 18 occasions, and in pulse pressure on 17. This was followed by a gradual decline over three or four beats, phasic and pulse pressures stabilizing at about the control value or a very little above them. When the supine position was resumed, there was a further slight fall in phasic pressures, usually to below the initial levels, the pulse pressure remaining more or less unchanged. In the course of about a further ten beats the blood pressure stabilized at approximately the initial control level. These changes were slight and somewhat inconstant in the children, but greater in extent and much more constant in the three adults in the series, none of whom was a squatter, and in whom seven of the observations were made.

\section{Discussion}

The patient with acyanotic congenital heart disease is able, at the cost of an increase in cardiac work, to maintain a systemic blood flow that is normal in amount and oxygen content. The patient with cyanotic congenital heart disease is at an extra disadvantage. Cardiac work is increased and, although the amount of blood reaching the tissues is normal in amount (Brotmacher and Deuchar, 1956), its oxygen content is reduced. It has been shown (Ernsting and Shephard, 1951, Holling, 1952) that, as a result of the polycythæmia, the removal of a given volume of oxygen from the blood during its passage through the capilliaries results in a relatively small drop in the percentage saturation of hæmoglobin. When the arterial oxygen content is below 80 per cent, the fall in oxygen tension between artery and vein is further minimized, owing to the form of the oxyhæmoglobin dissociation curve.

These compensatory mechanisms are only partly effective. In all but the mildest cases, despite a reduction in the arterio-venous difference, the resting percentage saturation of mixed venous as well as arterial blood is low (Holling, 1952). The capillary oxygen tension and, therefore, the tissue oxygen tension are correspondingly reduced, even at rest. It is against this background that the changes produced by squatting have to be viewed. Any benefits would, in the last resort, have to be associated with an increase in capillary oxygen tension, a decrease in cardiac work, or both.

The systemic blood flow was increased with squatting in most patients, both squatters and control subjects. The effective pulmonary blood flow and the veno-arterial shunts increased to approximately the same extent in the squatters, the arterial oxygen, which depends on the ratio of the shunt flow to the effective pulmonary flow, not being affected.

It is possible that, while the squatting position is adopted, blood is expressed from the legs, accounting for the momentary sharp rise in right atrial pressure. The increase in systemic flow may 
therefore be initiated by ventricular response to greater diastolic filling. The subsequent maintenance of the increase cannot, however, be related to increases in venous return from the legs, where the blood flow is reduced as a result of the obstruction to venous return that has been shown to be associated with squatting (Brotmacher, 1957b). The greater systemic flow cannot be secondary to expulsion of blood from venous reservoirs in the legs, as suggested by Lurie (1953), as the obstruction to venous return produced by squatting must, if anything, be associated with pooling of blood in the legs. Reducing the venous return from the legs by squatting might be expected to have an effect comparable to that produced by inflating cuffs on the thighs, although less in extent, as the obstruction to venous return is only partial. Inflating cuffs on the thighs has been shown, as would be expected from Starling's law, to reduce cardiac output (McMichael and Sharpey-Schafer, 1944). Starling's law, however, has been found of late to be inadequate as a sole explanation of the relation of cardiac output to venous return. Stead and Warren (1947) for instance, were able to produce simultaneous increases in cardiac output and reductions in venous return. They obstructed the arterial supply to the limbs by means of tourniquets, and when these were released, the reactive hyperæmia was associated with a considerable increase in cardiac output, even when the venous return was simultaneously reduced by inflating another set of cuffs placed proximally on all limbs to a pressure of $30 \mathrm{~mm}$. Hg. These observations show that factors other than the diastolic filling pressure can regulate the output of the heart.

Sarnoff and Berglund (1954) have recently modified Starling's law, introducing the concept of a " family of curves" relating ventricular stroke work to atrial pressure. They have shown in dogs that there is a close correlation between the two. When conditions are altered drastically, e.g. by administration of adrenaline, there is still a close relationship, but the curve relating the two is at a different level. The response of the heart is altered so that it may perform more work at a lower filling pressure, or less work at a higher level. Changes in atrial pressure will still, however, result in corresponding changes in stroke work.

When a patient squats, the partial obstruction to venous return from the lower half of the body tends to produce a lowering of the cardiac output. This probably accounts for the fall in systemic blood flow with squatting that was observed in two unanæsthetized patients and for the fall in effective pulmonary flow seen in four of the five patients anæsthetized for angiocardiography. The depth of anæsthesia was such that responses to external stimuli, although not abolished, were reduced considerably.

In most patients, squatters and controls alike, these tendencies are counteracted. The departure from the resting state associated with the change from the supine to the squatting position results in an increase in the cardiac output that is independent of changes in venous return. The heart, so to speak, moves to a different member of Sarnoff's family of curves. The increases in systemic flow are in this respect analogous to the increases in cardiac output in association with a reduction in venous return that were demonstrated by Stead and Warren (1947). Consequently, the higher right atrial and pulmonary capillary venous pressures observed throughout the period of squatting are probably not related causally to the increased systemic flow. They may be secondary to it or may result from changes in the pressure volume relationships of the atria.

The blood pressure changes with squatting that were observed are qualitatively similar to those described by Sharpey-Schafer (1956) in association with squatting while erect. The initial increase in systemic blood pressure with squatting is thought to be secondary to the increase in systemic blood flow. The subsequent blood pressure fall towards control levels is attributed to vaso-dilatation occurring as a baroreceptor response to the increase in pulse pressure. That this is slight and transient is immaterial. Sharpey-Schafer (1953) has shown that vaso-dilatation occurs in response to a single cough transient.

Vaso-dilatation is normally associated with increased blood flow and, in fact, a rise in forearm flow with squatting in the upright position has been demonstrated by Sharpey-Schafer (1956). It has also been found to occur when subjects squat when supine, an increase in forearm flow being observed in control subjects on ten occasions out of eleven and in squatters on nine occasions out 
of eleven (Brotmacher, 1957a). Squatting therefore results in a redistribution of the blood flow, which is reduced in the lower part of the body and increased in the upper.

Increases in right ventricular work are proportional to increases in overall systemic blood flow. Owing to the fall in leg blood flow, the rise in blood flow in the upper half of the body with squatting must exceed the overall rise in systemic flow and be relatively greater than the rise in cardiac work. There is, therefore, a relative economy in cardiac work.

Children who are habitual squatters can adopt the position effortlessly, whereas control subjects, unaccustomed to the posture, find it somewhat uncomfortable and progressively more difficult to maintain. These differences are most obvious when patients squat while upright, but were clearly evident when observations were being made on the effect of squatting while supine. In the control subjects, the difficulty in squatting results in a general increase in muscle tone and movement. This is thought to account for an increase in oxygen requirements and a consequent absence of any consistent increase in the oxygen content of venous blood from the upper half of the body, despite the increase in systemic flow. In the squatters, on the other hand, there is little or no increase in muscle tone or activity, apart from in the legs, and, therefore, little or no rise in oxygen requirements. Consequently, in these patients, increase in blood flow in the upper part of the body with squatting is associated with a consistent increase in the oxygen content of superior vena caval blood.

The increase in blood flow to the upper half of the body with, in the squatters, a reduction in the coefficient of oxygen utilization and an increase in the oxygen content of superior vena caval blood signifies an increase in capillary oxygen tension in that part of the body. The absence of changes in arterial oxygen is relatively less important as capillary oxygen tension is related more closely to venous than to arterial oxygen tension (Barcroft, 1934).

The lessening of the anoxia in the part of the body that contains the vital centres and is the most sensitive to anoxia is accomplished with a relative economy in cardiac work. It is thought to account for the increased well-being associated with squatting, and to explain the tendency for patients with severe forms of cyanotic congenital heart disease to squat independently of exertion.

\section{SUMMARY}

The reasons why children with severe forms of cyanotic congenital heart disease tend to squat continuously while recumbent have been investigated. Squatting results in an increase in systemic blood flow in habitual squatters and in control subjects. In patients with cyanotic congenital heart disease the rise in systemic blood flow is usually the result of an increase in both the effective pulmonary blood flow and the veno-arterial shunt. Squatting reduces the blood flow in the legs: there is a redistribution of the output of the heart as a result of which the increase in systemic flow is confined to the upper part of the body.

In habitual squatters the increased systemic flow is not associated with a corresponding rise in tissue oxygen requirements and there is consequently, in the upper part of the body, a lessening of the arterio-venous oxygen difference. The oxygen content of arterial blood remains unchanged, but that of venous blood increases and capillary and tissue oxygen tension are therefore raised. This reduction in anoxia in the part of the body that contains the vital centres and is the most sensitive to oxygen lack is thought to be the basis of the benefits obtained by patients with cyanotic congenital heart disease who squat continuously while recumbent.

I should like to thank Dr. Maurice Campbell for his advice and help in this investigation.

\section{APPENDIX}

The possibility that the beneficial effects of squatting are partly secondary to abdominal compression was suggested by Lurie (1953), who considered this factor important when subjects squat in the upright position. He thought that squatting results in compression of reservoirs of blood in the abdomen as well as the legs; it thus counters the effects of gravity, which causes a fall in cardiac output in the erect position, owing to pooling of blood in the lower half of the body. 
The effect of squatting in the supine position on intra-abdominal pressure was investigated in five patients with pulmonary tuberculosis in whom this pressure was measured before pneumoperitoneum refills. Squatting resulted in pressure increases of 4 to $8 \mathrm{~mm}$. $\mathrm{Hg}$. It was found that increases of this order could be produced by inflating a cuff applied to the abdomen to a pressure of $50 \mathrm{~mm}$. $\mathrm{Hg}$. This method was then used to study the effects of abdominal compression on blood flow in the arms and legs and on the overall systemic flow. These were measured by venous occlusion plethysmography and at cardiac catheterization respectively.

None of the effects of squatting could be reproduced by abdominal compression. In four squatters and six control subjects the mean blood flow in the legs was increased by $0 \cdot 2$ and $0.1 \mathrm{ml} . / 100 \mathrm{ml}$. respectively. Forearm flow was increased in a group of eight control subjects, but the mean change was very small and not significant (mean increase $=0.2 \mathrm{ml} . / 100 \mathrm{ml}$., $t=1 \cdot 0,0.4>P>0.3$ ). In six control subjects, the overall systemic blood flow was reduced significantly by abdominal compression (mean reduction $=16 \%, t=3 \cdot 61$, $0.02>P>0.01$ ), which probably has an effect on the venous return similar to that of cuffs on the thighs.

It is concluded that the beneficial effects of lying continuously in a squatting position are not related to the small increase in intra-abdominal pressure that is produced.

\section{REFERENCES}

Barcroft, J. (1934). Features in the Architecture of Physiological Function. Cambridge.

Brotmacher, L. (1957a). University of London Thesis. (1957b). Brit. Heart J., 19, 567. , and Deuchar, D. C. (1956). Clin. Sci., 15, 441.

Callebaut, C., Denolin, H., and Lequime, J. (1949). Acta cardiol., 4, 324.

Christie, R. V., and Donald, K. W. (1949). Clin. Sci., 8, 21.

Douglas, C. G., and Priestley, J. G. (1948). Human Physiology. 3rd ed., Oxford University Press, Oxford.

Ernsting, J., and Shephard, R. J. (1951). J. Physiol., 112, 332.

Holling, H. E. (1952). Clin. Sci., 11, 283.

, and Zak, G. A. (1950). Brit. Heart J., 12, 153.

Lurie, P. R. (1953). Amer. J. Med., 15, 297.

McMichael, J., and Sharpey-Schafer, E. P. (1944). Brit. Heart J., 6, 33.

Sarnoff, S. J., and Berglund, E. (1954). Circulation, 9, 706.

Sharpey-Schafer, E. P. (1953). J. Physiol., 122, 351. (1956). Brit. med. J., 1, 1072.

Stead, E. A., Jr., and Warren, J. V. (1947). Arch. intern. Med., 80, 237.

Taussig, H. B. (1947). Congenital Malformations of the Heart. Commonwealth Fund, New York. 